\title{
A Case Study of Teacher Engagement in Partisan Politics and It's Influences on Students Learning and Classroom Practices: Perspective on Bangladesh
}

\author{
Mohammad Omar Shiddike ${ }^{1, *}$ \\ ${ }^{1}$ Faculty of Education, University of Regina, Saskatchewan, Canada \\ *Correspondence: Faculty of Education, University of Regina, 3737 Wascana Pkwy, Regina, SK S4S 0A2, Canada. \\ Tel: 1-306-580-1030. E-mail: shiddikm@uregina.ca
}

This work was financed by Regina Public Interest Research Group and the Faculty of Graduate Study and Research of the University of Regina, Canada.

Received: April 9, 2019

Accepted: May 10, 2019 Online Published: June 5, 2019

doi:10.5430/wje.v9n3p22

URL: https://doi.org/10.5430/wje.v9n3p22

\begin{abstract}
The main purpose of this study is to uncover the various ways in which teacher engagement in partisan politics goes ahead to influence the delivery of the teacher in the classroom as well as the learning of the students in higher education institutions in Bangladesh. The sole approach to the study focuses on two higher education institutions in Bangladesh as the study focused on how teacher engagement in partisan politics goes ahead to affect the learning of the students as well as the professional output of the teachers. Through the framework provided by the literature review, the qualitative study went ahead to explore both individuals as well as collective opinions which went to show that indeed partisan politics did indeed affect the professional duties of the teachers leading to implications to the students as well.
\end{abstract}

Keywords: engagement, teacher engagement in politics, faculty engagement in teaching, Bangladesh teacher education, Bangladesh politics, student learning, classroom teaching, case study research

\section{Introduction}

Bangladesh is a small country with a land area of 51, 703 sq. Miles with a population of 166, 280,712 according to the 2014 estimates. This, therefore, goes to show that the nation is densely populated and after the 46-year freedom from colonization, the reports still indicate a literacy level which is below 57\% (Bangladesh Bureau of Educational Information and Statistics, 2013). In order to deal with this, the government is trying to increase the national literacy levels through insisting on the importance of education through public channels such as mass media which will be able to create awareness among both parents and students while at the same time urging them to go to school. However, in spite of the government's intentions, the relevant authorities seem not interested in addressing the issue of teacher engagement in partisan politics as well as how this affects the learning in the institutions. Instead, the government and the opposition parties influence the teachers to engage in further partisan politics which affects their professional delivery (Nazrul, 2016). As a result of such encouragement given by the political parties, the teachers in Bangladesh, mostly those working in higher education institutions engage in partisan politics even in their classrooms sharing their ideologies with the students in an attempt to get the students to view political affairs with respect to their individual views.

In addition, from independence to till today the Bangladeshi people are still in a struggle to meet their needs as well as necessities (Knox, 2009). In order for such a society to fully develop and grow, classroom teaching becomes imperative for the citizens to focus on education as this creates a population which is literate and has the ability to formulate better working policies and rules which will ensure development in the country (Knox, 2009). Knox also states that the entire population of Bangladesh views teachers as key leaders and personnel who have the capacity to develop as well as sustain an educated country which will in effect assist the students to fully realize the better future 
the whole nation aspires to achieve.

Teaching is also considered as a key component which will make sure the entire nations education system becomes successful and effective for the aspiring student minds. Nelson and Hammerman, (1996) state that "Teaching as a general practice is based on the assumption that knowledge is constructed, dynamic and conditional" (p. 8). Nelson and Hammerman also indicate that teaching is not a politically neutral activity but may be driven by the teacher's ideology in teaching. Teaching is viewed as a moral activity by the citizens (Fenstermacher, 1990), as well as an intellectually and morally complicated work (Ball and Wilson 1996; Lampert, 1985). What is always expected of teachers is to share their love and quest for knowledge with the students through giving them the needed direction in the path of achieving their learning goals.

\section{Literature Review}

In the nation of Bangladesh, each and every generation has followed their teachers as a guiding symbol of role models within their generations (Ball and Wilson, 1996). Through this, the nation has been able to learn indifferent behaviors, attitudes, expressions as well as certain ideas which will eventually assist them in becoming all round productive citizens. Apart from the learning, the teachers are expected to mold the students' moral values in teaching them what is right from what is wrong, the difference between honesty and dishonesty and basically what should be done to fully adapt to the environment that is today which is crucial to the growth of future generations (Lumpkin, 2008). Limpkin further declares that it is the duty and mandate of teachers to assist the students in exploring societal questions as well as the socio-cultural demands of life. From the beginning of formal schooling to higher education, the citizens of Bangladesh do believe that students become fully dependent on their teachers which definitely means that a lot of what they know is influenced by the teachers.

One of the problems being faced in Bangladesh is that most of the teachers who are employed in the formal educational institutions such as universities do participate broadly in national partisan political affairs in the classroom (Masum, 2008). As citizens interested in the running and the governance of the nation, they regularly engage in political meetings as well as forums where they get the chance to show and express their political views as well as show their support for certain political parties. Presently, the country has four major political parties which include Bangladesh Awami League (BAL), Bangladesh Nationalist Party (BNP), Bangladesh Jatio Party (BJP) and Jamayati Islam Bangladesh (JIB) (Alam, Rabby, Boon, Khan, and Hoque, 2011). Every citizen in the country is definitely proud to show their affiliation with certain political parties this also including teachers. The problem, however, stems from the fact that this engagement in the partisan politics usually tends to influence their classroom professional practice which eventually ends up rubbing off on the students.

Another problem here is that the teachers in Bangladesh also use various traditional teaching methods such as creating a heavy reliance on the lectures and the use of certain resources which are already outdated and cannot be further used to pass on education (Rabbani and Chowdhury, 2014). Such a problem is however brought about by the fact that teachers have limited engagement in academic research as well as little time to help promote their professional activities (Monem and Baniamin, 2010). Monem and Baniamin also claim that a great number of the university lecturers do spend a little time as well as their professional abilities to come up with better teaching materials as well as engage in academic research due to the inadequate opportunities nationwide for professional development. Monem and Baniamin further claim that the teachers usually side with the party leader's patronage which makes them to appear to be driven by personal motives as well as the choices in their work as teachers rather than the ethos of their profession. This article will seek to explore the various potential implications of teacher participation in partisan politics as well as their activism in the classroom might, in the end, impact their professionalism.

In the country of Bangladesh, a common perception held by the citizens is that most of the students do follow their teachers as role models expected to guide them from what is good or bad. When public schools were established in the US between the $18^{\text {th }}$ and the $19^{\text {th }}$ centuries, the main motives for their establishment was to be able to teach students moral values (Mondale and Patton, 2001; Mulkey, 1997). Lickona (1991) stated that both schools and teachers should focus on student education with most reference being through character bordered on respect as well as character. Teachers do interact with students on a regular basis from their classrooms which makes it vital for them to act as character role models who should assist them in making up professional judgements. Most of the students pick this up according to how the teachers carry themselves within the institution (Hansen, 2001). This therefore goes to show that the moral of teachers in the learning institutions according to Campbell, works well to shape the university students' morals. Such behaviors from the teachers adopted by the students gives them a much greater 
moral as well as an exemplary role in the development of the nation (Campbell, 2008).

The citizens in the country of Bangladesh do believe that most of the teacher activities have a lot of influence on the students. They are expected to both introduce as well as establish new better paths for their students where the young minds can follow through the path to success (Hansen, 2001). From this, it becomes quite obvious that teacher activities as well as attitudes and behaviors in the classroom become significant to the development of students in higher institutions. Ajzen (2005) claims that the attitudes of teachers have a great influence on their behaviors within the classroom, this happening even though of certain occasions, teachers do not practice some of the attitudes they espouse (Argyis and Schon, 1978).

\section{Statement of Study and Research Questions}

The key questions to be answered with the study include the ways in which teacher engagement in partisan politics creates an influence the professional practices in the classroom. This includes their delivery of educational content to the students they serve in the classrooms as well as research more educational information which can benefit the students in the country through the formation of a better university syllabuses. Another question to be answered in the study is how the engagement in the partisan politics will in effect influence the learning of students. This involves the influence of students to participate in partisan politics which can in effect lead to a political divide in the universities. Such can culminate into institutional violence which will definitely be dangerous to the students as well as the institution itself.

As employed in this study, partisan political involvement stands for the action of a teacher who is fully involved with offering active support to a political party of choice. According to Norris (2000), the three components of the canonic definition of political engagement relate to the political participation, political information as well as political trust. This, therefore, goes to show that partisan political engagement has the ability to take various forms which include being an active member of a political party. With this, they follow the ideas of the party and the leaders, contributing funds in support of the party as well as working or volunteering on party campaigns; they also attend the party meetings as well as fully support the party's agenda. The intention of partisan political engagement is intended to influence political action through the discussion of partisan politics with others which is the sole approach in this study. Here the teachers try to convince the students to join with their political parties which will in effect have the students convincing more students about the same. Partisan political engagement also includes actions such as teachers who might take to influence the behaviors of those who are empowered to make decisions in the party or the government. It includes the actions intended to influence decision making both inside and outside the government through the application of political pressure. Partisan political engagement also features the actions which the teachers might adapt in the influencing of both governments as well as non-government decision makers through the mobilization of public opinion. In this light, the teachers immersed in partisan politics would therefore in no doubt be involved in various forms of political action as a sign of support to their political parties (Alam et al., 2001; Monem and Baniamin 2010).

Pratt and Associates (1998) have discussed five perspectives on teaching in adult as well as higher education. The first perspective is the transmission perspective which involves the effective delivery of content. The apprenticeship perspective which looks at teaching as something which helps students in the modeling of their being. The third perspective is developmental which assists in the cultivation of thinking ways which includes the development of critical thinking skills. There is also the nurturing perspective which borders on the facilitation of self-efficacy is students within the learning process. Lastly, the social reform perspective which works on seeking a better society through both teachings as well as education in general.

\section{Research Methodology}

\subsection{Qualitative Research Approach}

One of the research methods used in the study is the qualitative research approach. This sort of research approach follows certain procedures from the traditional research methods. Here, a research problem is presented, for instance, the case of discussion in Bangladesh, the relevant research questions are posed and the relevant data is collected, analyzed and interpretation is made to answer the research questions fully (Creswell, 1998). A qualitative research contains certain features which render it different from a quantitative approach such as the fact that the research topics are mostly "emotion laden, close to the people and practical" (Creswell, p. 18). The research questions are mostly open-minded to allow the participants' perspectives to be fully explored. There are also no "best" questions and instead, the research process proceeds, the questions may change to show an increased understanding of the 
problem. A qualitative study typically collects data from various sources with the basic types of information gatherers being interviews, observations, audio visual materials as well as documents. The data to be presented is partially based on the participants' views as well as partially on the researcher's interpretation of those views. The entire process of conducting the research as well as the participant's ideas are shaped into a narrative story which can be presented (Creswell, 1998). Ragin (1992), qualitative research fully relies on various factors as well as a few cases while on the other hand, the quantitative research looks on few variables as well as many cases. Instead of looking at the relationship between variables, the study also explored the manner in which teacher engagement in partisan politics in two Bangladeshi higher education institutions in one way or the other influenced the learning process as well as the institutions where they worked. The qualitative approach was able to produce a descriptive account of teacher engagement in partisan politics from the perspectives of the four teachers who worked at higher education institutions in Bangladesh.

\subsection{Case Study Methodology}

The case study research design would definitely have to fall under the most suitable approaches for the study. This is because of the methods ability to incorporate a wide range of evidence which includes documentation, interviews as well as observations and artifacts. The qualitative research approach is one that has been used in the exploration of teacher engagement in partisan politics as well as how such engagement impacts their professional classroom practices. As a research methodology, the case study is seen as a qualitative approach where the investigator looks at a single bounded system as well as multiple bounded systems over time through the detailed, in-depth data collection processes which involve various information sources which include interviews, observations, documents, reports as well as audio visual material. These assist in the provision of case description as well as case-case based themes (Creswell, 2007, p.73). The case might be a relatively bound object or a process being either theoretical, empirical or an association of both (Regin and Backer, 1992). At a minimum, a case becomes a phenomenon specific to both times as well as space. Case studies are also particularistic, heuristic as well as descriptive in nature given that they allow the researcher the identified cause (Merriam, 2009). Merriam continues further by stating that particularistic becomes quite vital for what is eventually revealed regarding the event or what it might eventually represent. She further argues that the descriptive aspects of the case studies denote the fact that the said product is complete and a literal description of the event is investigated. For the study, applying a qualitative case study becomes most appropriate as it adequately answers the research questions in achieving the purpose of the study. This is also because the case study researcher is quite interested in a full understanding of the holistic nature of a problem through the use of one or two illustration cases. The following case involved the full exploration of the individual as well as the collective opinions given by the four teachers with respect to their engagement in national partisan politics. The use of a case study methodology was instituted by the goal of getting individuality in each case as well as ensure that all information about the case was well presented.

\section{Results}

One-on-one audio taped interviews were conducted between the months of December 2014 and January 2015. The resultant interview data was organized into thematic categories according to the research purpose and questions. The categories which had a relationship to the manner in which teacher engagement in national partisan politics influenced their professional practice as well as the learning of the students and the institutions where they worked for. The study's findings also explored the perspectives of the participants on teaching. In spite of the key focus of the study being the participation of teachers in partisan politics in Bangladesh, some of the received perspectives on higher education teaching became crucial as such discussion would help place their views on the matter in a much bigger institutional context. The thought along with the study was that the participants' perspectives on teaching being included would assist in the better understanding of their views on their engagement in partisan politics. The assumption made was that some relationships were likely to exist between the manners in which the participants talked about their perspectives on teaching as well as their engagement in partisan politics.

Professor Dr. Mohid actively engaged in partisan politics in the country. However, despite his indulgence in partisan cautioned teachers against losing focus on their professional duties and instead focus on partisan politics. This does not take away the fact that he still acknowledged the fact that teachers have the right to support a political party of their choice as long as it does not in any way affect the delivery of their service. This goes in line with the fact that teachers are also citizens and it is their duty to participate in civic responsibility such as belonging to a political party. However, the professor goes against this if it affects their position as teachers. This, therefore, means that outside of work, there is no problem with indulging in partisan politics. However, they should in no way try to influence 
students as this will be a neglect of their primary responsibilities.

The professor also viewed teaching as the noble act of passing knowledge to the hungry students and when asked the reason as to why teachers engage in partisan politics, he said the main reasons is because of the 1973 rule as well as for their personal benefits. The 1973 rule refers to the Public University Ordinance which seems to be the major reason for politicization of universities (Middlehurst and Woodfield, 2004).

The second participant, Professor Dr. Mabina views teaching as the effective delivery of subject matter to students which is a quantitative increase in knowledge. She viewed the teaching perspectives of most of the Bangladeshi teachers to be similar as all see learning as the gaining of knowledge from the students. Asking her whether the engagement in partisan politics affected classroom practice, she replied that indeed it does affect. This is because most students see their teachers as role models and as a result, many may be influenced into pursuing politics as well. Teachers may become unethical in grading students according to party affiliations.

The third participant Professor Dr. Mapas believes that teachers have the right to be associated with any political party as long as it does not transcend all the way to the classroom. When asked about the engagement of partisan politics in the classroom he went ahead to justify the involvement of teachers in partisan politics but vehemently denounced the activities being carried out at a classroom level. He also goes to claim that the engagement in partisan politics will only toxic to both the teaching profession and the students learning. He claims that the teacher engagement in national politics affects the effectiveness of teachers in the classroom. When asked about the effects brought about to the institutions due to teacher engagement, he claimed that the reputation of the institutions is bound to suffer as no professional development or academic research will not be encouraged.

The last participant, Dr. Rakhina feels that teaching is not only a profession but something special significant which involves caring for the nation's sons as well as daughters. She, therefore, goes further to state that teaching should be considered as a first priority even though it is important for teachers just like any citizens to engage in partisan politics to enable national growth and development. She believes that teaching students also helps in the development of the student's future as well as caring for the next generation. She defines teaching as a method that conveys knowledge to students so that they may be excellent future prospects in whatsoever fields. Just like her fellow teachers at the higher education level, she believes that the engagement in partisan politics only results in major problems for the entire institutional fraternity. She argues that this takes time away from professional duties and responsibilities and thus limits the delivery of the teachers in schools. She shares similar views to her colleagues stating that teachers should focus on teaching the syllabus instead of incorporating irrelevant political agendas which may not offer any good results for the students. She indicated that the engagement in partisan politics affects student learning and that no eventual benefits will be achieved from the practice.

\section{Discussion}

The findings of the study revealed that all the participants shared identical perspectives on the engagement of partisan politics by teachers in the university environment. According to work done by Pratt and Associates (1998), teaching is viewed as the effective delivery of both knowledge and academic content to the students. The same views have been held with all the four participants who view teaching as something completely crucial to their professions. According to the findings, teachers should carry themselves as the content experts they see themselves as with their primary responsibility being the delivery of educational content to their students effectively and efficiently.

The findings of the study revealed that partisan political engagement in the classroom took away the needed preparation time where the teachers end up neglecting their professional responsibilities which includes things such as teaching, research as well as publication. All the participants in the study agreed that the engagement in the partisan political activities gave them inadequate time to focus on their professional duties which include things such as class preparation which leads in the undermining of their effectiveness and efficiency in service delivery. Despite all the teachers in the study agreeing that the engagement in partisan politics affected their service delivery to their students, they agreed that teachers just like other citizens have the right to be involved in national politics. This, therefore, means that teacher engagement in partisan politics is justified as long as it does not become adopted in classroom activities.

Teacher engagement in partisan politics has grave effects on students learning as seen by all the participants of the study. The same can also be said with regard to personal experience as a Bangladeshi national and from the literature perspective that indeed the engagement in partisan politics affects student learning. This will make the students focus less on their studies as various political branches can be formed within the higher institutional environment leading to issues of violence due to political misunderstandings. With such violence, campus strikes can be caused which will 
lead to injuries, death and massive destruction of institutional property. The engagement in this will lead to certain students of similar political affiliations as the teachers being favored while those of different parties being failed. This is definitely a move which fully goes against the professional learning process in educational institutions.

Lastly, the findings on the influence of the teacher engagement in partisan politics reveal that all the research participants believed that the practice brought ill representation to the institutes of higher learning. This is because such academic institutions solely depend on the quality of academic work given by the institutions and therefore the lack of this causes a negative to the sole intentions of the institutions. The quality of learning gets compromised by the teachers while discussing partisan political affairs which eventually causes a lag in the educational system in the institution. As a profession, teachers need to spend the better time of their class work in developing materials which will be useful for the students' academic development. Engaging in the partisan politics causes an obstacle to learning which will eventually reflect in the entire institution's image.

\section{Suggestions}

This study can end up offering more valuable as well as crucial information towards the case of teachers being engaged in partisan politics in higher education institutions in Bangladesh. The study also would be quite helpful in the comparison of views of the lecturers participating in such and have served quite a long term in the profession as well as those starting out in the higher education fraternity. The issue also calls for broader sampling as well a comprehensive study which will seek to involve all the major stakeholder groups leading to the issue and those affected in the aftermath. The stakeholders include; the political party officials, the university students, the institutions administration, the parents to the students as well as the participating teachers. Through the inclusion of such, the study will have a broader conception on the implications which arise from the teacher engagement in partisan politics. On a larger scale, it will be more beneficial if the study is conducted in other professions in the country such as lawyers, doctors as well as other occupations which may end up being affected by the same. It would be more imperative for a study to be conducted on the teachers who do not participate in partisan politics and the results compared to this study which eventually will lead to the provision of more insightful as well as valuable information. If the study is replicated for the entire country of Bangladesh, this including also secondary school as well as primary school teachers, the information provided would be rich placing more light to the magnitude of the issue. Lastly, a study should be conducted to explore the engagement of workers in other parts of the national economics who participate in bipartisan politics. Such a study could prove to be very helpful for the nation's economic and social development.

\section{Conclusion}

It, therefore, goes without saying that the study concludes the engagement of teachers in partisan politics in Bangladesh has fully influenced the nation's professional practices in universities in more than one way. After the study, the participants provided adequate evidence to show the impacts of the participation in partisan politics which eventually harms the national higher education performance. They also suggested that the act had certain benefits as well as challenges to the teachers causing a great imbalance in the national employment of teachers with those not deserving getting better opportunities than those who deserved. The participants came to a contentious that the 1973 Ordinance became one of the core reasons as to why the university lecturers became quite endorsed in the national partisan politics. The suggestions from all the participants were for the teachers to focus on their profession delivery instead of accompanying this with partisan responsibilities which cause great effects eventually. Bangladesh is a small country with various social, political and economic issues. It, therefore, depends on the education of all the citizens so as to develop in these aspects. The teachers, therefore, become quite important for this step to be accomplished and this, therefore, means that quality education has to be offered outside of the partisan participation of the citizens.

\section{References}

Ajzen, I. (2005). Attitudes, personality and behavior (2nd ed.). Maidenhead, UK: Open University Press.

Alam, G. M., \& Hoque, K. E. (2010). Who gains from "brain and body drain" business-developing/developed world or individuals: A comparative study between skilled and semi/unskilled emigrants. African Journal of Business Management, 4(4), 534-548.

Alam, G. M., Hoque, K. H., Rout, G. K., \& Priyadarshini, N. (2010). Who does gain from EFA-State business of education or private higher education in developing nation: A study to understand the policy impact in Bangladesh? African Journal of Business Management, 4(6), 770-789. 
Alam, G. M., Rabby, T. G., Boon, T. L., Khan, I., \& Hoque, K. E. (2011). National development and student politics in Bangladesh. African Journal of Business Management, 5(15), 6044-6057. https://doi.org/10.5897/AJBM11.813

Alam, M., Haque, M. S., \& Siddique, S. F. (2007). Private higher education in Bangladesh. Research papers. Paris: International Institute for Education Planning. Retrieved from www.unesco.org/iipe/pdf/pubs/Bangladesh.pdf

Argyris, C., \& Schon, D. (1978). Organizational learning: A theory of action perspective. Reading, Mass: Addison Wesley. https://doi.org/10.1177/017084068000100310

Ball, D. L., \& Forzani, F. M. (2007). What makes education research educational? Educational Researcher, 36(9), 529-540. https://doi.org/10.3102/0013189x07312896

Ball, D. L., \& Forzani, F. M. (2009). The work of teaching and the challenge for teacher education. Journal of Teacher Education, 60(5), 497-511. https://doi.org/10.1177/0022487109348479

Ball, D. L., \& Wilson, S. W. (1996). Integrity in teaching: Recognizing the fusion of the moral and the intellectual. American Educational Research Journal, 33, 155-192. https://doi.org/10.3102/00028312033001155

Bangladesh Bureau of Educational Information and Statistics (BANBEIS). (2013). Bangladesh Education Statistics. Retrieved from http://www.moedu.gov.bd/index.php?option=com_content\&task=view\&id=321\&Itemid=229

Bangladesh Bureau of Educational Information and Statistics (BANBEIS). (2004). A Study on Higher Education in Bangladesh. Retrieved From http://www.banbeis.gov.bd/webnew/images/edusystem.pdf

Bogdan, R.C., \& Biklen, S.K. (1992). Qualitative research for education: An introduction to theory and methods. Boston, MA: Allyn \& Bacon.

Boje, D. (2002). Narrative inquiry: Experience and story in qualitative research. Human Relations, 55(6), 731-745.

Campbell, E. (2008). The ethics of teaching as a moral profession. In curriculum inquiry [online]. The Ontario Institute for Studies in Education, 38(4), 357-385. https://doi.org/10.1111/j.1467-873x.2008.00414.x

Chowdhury, K. P. (1997). Bangladesh in Gerald A. Postiglione and Grace C. L. Mark, Asian higher education: An international handbook and reference guide (pp.1-20). New York, NY: Green Wood Press.

Creswell, J. W. (1998). Qualitative inquiry and research design: Choosing among the five traditions (1st ed.). Thousand Oaks, CA: Sage Publications. https://doi.org/10.1086/317417

Creswell, J. W. (2007). Qualitative inquiry and research design: Choosing among five approaches (2nd ed.). Thousand Oaks, CA: Sage.

Dey, I. (1993). Qualitative data analysis: A user-friendly guide for social scientists. London, England: Routledge.

Fenstermacher, G. D. (1990). Some moral considerations on teaching as a profession. In J.J. Goodlad, R. Soder, \& K.A. Sirotnik (Eds.), The moral dimensions of teaching (pp. 130-151). San Francisco: Jossey-Bass. https://doi.org/10.1177/002248719104200309

Guba, E. G., \& Lincoln. Y. S. (1989). Fourth generation evaluation. New Delhi, India: Sage Publications.

Hansen, D. T. (2001). Teaching as a moral activity. In V. Richardson (Ed.), Handbook of research on teaching, (4 ${ }^{\text {th }}$ ed.) (pp. 826-857). Washington, D. C.: AERA.

Hoque, K. E., Alam, G. M., \& Abdullah, A. G. K. (2011). Impact of teachers' professional development on school improvement-an analysis at Bangladesh standpoint. Asia Pacific Educ. Rev, 12, 337-348. https://doi.org/10.1007/s12564-010-9107-z

Khan, M. M. (2010, March 26). State of public universities in Bangladesh. The Daily Star, p.10.

Knox, Colin. (2009). Dealing with sectoral corruption in Bangladesh: Developing citizen involvement. Wiley Inter Science, 29, 117-132. https://doi.org/10.1002/pad.523

Kvale, S. (1996). Interviews: An introduction to qualitative research interviewing. Thousand Oaks, CA: Sage.

Lampert, M. (1985). How do teachers manage to teach: Perspectives on problems in practice. Harvard Educational Review, 55920, 178-194. https://doi.org/10.17763/haer.55.2.56142234616x4352

Lather, P. (1986). Issues of validity in openly ideological research: Between a rock and a soft place. Interchange, 17(4), 63-84. https://doi.org/10.1007/bf01807017

Lincoln, Y. S., \& Guba, E. G. (1985). Naturalistic inquiry. Newbury Park, CA: Sage. 
Lumpkin, A. (2008). Teachers as role models teaching character and moral virtues. Journal of Physical Education, Recreation\& Dance, 79(2), 45-50. https://doi.org/10.1080/07303084.2008.10598134

Masum, M. (2008). Higher education in Bangladesh: Problems and politics. Journal of the World Universities Forum, $1(5), 17-30$.

Merriam, S. B. (2009). Case study research in education. San Francisco, CA: Jossey-Bass.

Middlehurst, R., \& Woodfield, S. (2004). The role of transnational, private and for-profit provision in meeting global demand for tertiary education: Mapping, regulation and impact-case study Bangladesh. Vancouver, BC: Commonwealth of Learning and UNESCO.

Mondale, S., \& Patton, S. B. (2001). School-The story of American public education. Boston, MA: Beacon.

Monem, M., \& Baniamin, H. M. (2010). Higher education in Bangladesh: Status, issues and prospects. Pakistan Journal of Social Services (PJSS), 30(2), 293-305.

Nazrul, A. (2016, January 13). Secretary VS Teacher. The Daily Amader Shomoy, p. 1.

Nelson, B., \& Hammerman, J. (1996). Reconceptualizing teaching: Moving toward the creation of intellectual communities of students, teachers, and teacher educators. In M, Mclaughlin and I, Oberman (Eds.), Teacher learning new policies, new practices, (pp. 3-21). New York, NY: Teachers College Press.

Norris, P. (2000). A Virtuous Circle: Political Communications in Post-industrial Societies. Cambridge, MA: Cambridge University Press.

Pratt, D. D., \& Associates (1998). Five Perspectives on Teaching in Adult and Higher Education. Malabar, FL: Krieger Publishers.

Rabbani, G., \& Chowdhury, S. (2014). Quality of higher education in Bangladesh: Governance framework and quality issues. Beykent University of Social Sciences, 7(1), 78-91. https://doi.org/10.18221/bujss.86058

Regin, C. C., \& Backer, H. S. (1992). What is a case? Exploring the foundations of social inquiry. Cambridge, MA: Cambridge University Press.

Strauss, A. L., \& Corbin, J. M. (1998). Basics of qualitative research: Techniques and procedures for developing grounded theory. Thousand Oaks, CA: Sage Publications. https://doi.org/10.4135/9781452230153 